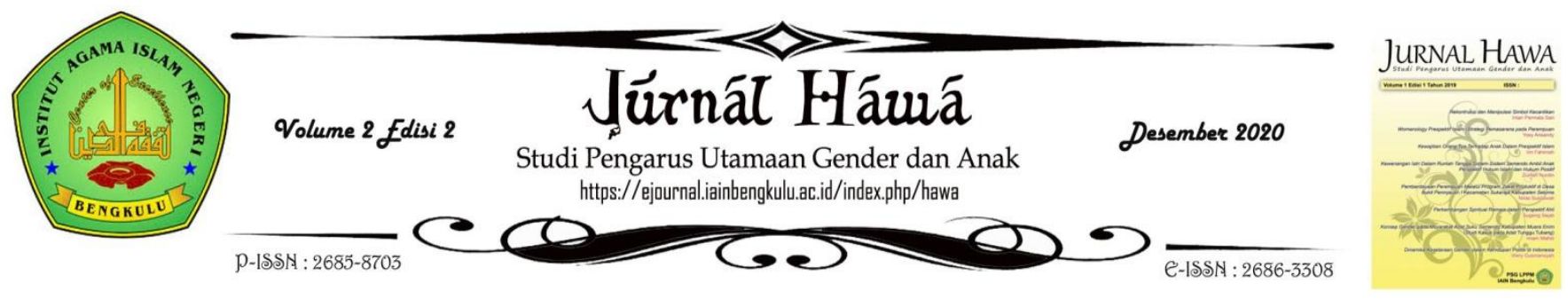

\title{
Kebaya: Belenggu Konservatif Perempuan Muslim
}

\section{Info đrtikel}

Diterima: November 2020

Disetujui: November 2020

Dipublikasikan:

Desember 2020

\section{Keyword}

Women,

kebaya, and

Moslem

\section{Kata \\ Kunei \\ Perempuan; \\ Kebaya; \\ Muslim}

\author{
Fitrayani Dian Rositadewi \\ Universitas Gajah Mada \\ fitra20@gmail.com
}

\section{Abstract}

Kebaya as clothing that is identical to Indonesian identity has undergone changes in line with modernization. This change, apart from encouraging adaptations that must be carried out by women, also has implications for female values. This paper explains how changes in the existence and use of the kebaya as women's clothing have become the basis for the values and norms imposed on women. Kebaya modifications in various forms also become a configuration that forms the inherent values of women. Given that the kebaya is also the clothing of Muslim women, the kebaya has presented an interaction between culture and religion in its use. In other words, the times that were adapted to clothing have also changed perceptions of women's identity.

\section{Tlbstrak}

Kebaya sebagai pakaian yang identic dengan identitas Indonesia telah mengalami perubahan sejalan dengan modernisasi. Perubahan ini selain mendorong adanya adaptasi yang harus dilakukan oleh perempuan juga telah berimplikasi pada nilai-nilai keperempuanan. Tulisan ini menjelaskan bagaimana perubahan di dalam keberadaan dan penggunaan kebaya sebagai pakaian kaum perempuan telah menjadi dasar nilai-nilai dan norma yang dikenakan pada perempuan. Modifikasi kebaya dalam berbagai bentuk juga menjadi konfiguransi yang membentuk nilai-nilai yang melekat pada perempuan. Mengingat kebaya juga menjadi pakaian perempuan muslim maka kebaya telah menghadirkan interaksi antara budaya dan agama dalam penggunaannya. Dengan kata lain, perkembangan jaman yang diadaptasikan dalam pakaian juga telah mengubah persepsi tentang identitas perempuan. 


\section{Pendahuluan}

Tubuh manusia sebagai kajian yang sentral dalam siklus hidup menjadi kegiatan statis sejak lahir hingga mati. Sikap perlakuan tubuh pada setiap ruang yang dimasuki akan berbeda - beda. Hal tersebut disebabkan oleh keberadaan tubuh sebagai bagian dari struktur sosial masyarakat sehingga terdapat nilai yang melekat pada tubuh dan bersifat lentur terhadap situasi dan kondisi keruangan. Nilai dan norma dalam masyarakat menyangkut kontrol publik terhadap tubuh manusia. Tubuh manusia merupakan tubuh sosial yang mampu untuk berhubungan dengan tubuh yang lain melalui respons atas lingkungan alam maupun respons biologis sebagai karakter tubuh. Dalam perjalanannya, manusia berinteraksi dengan manusia lainnya melalui tubuh masing - masing, melihat kesamaan ciri fisik seperti warna kulit, bentuk tubuh, rambut, dan lain - lain.

Tubuh secara fisik lambat laun mengalami transformasi kepemilikan dari individual menjadi komunal, sehingga tubuh berasosiasi dengan nilai - nilai sosial yang hidup dalam masyarakat di mana ia tinggal. Transformasi tersebut menjadi poin penting yang perlu diperhatikan oleh manusia dalam memperlakukannya di ruang sosial karena akan berdampak pada disposisi tubuh dan interaksinya dengan lingkungan sosial. Kontrol sosial atas tubuh berpengaruh terhadap penilaian yang diberikan oleh masyarakat terhadap tubuh individu, maka penting memperhitungkan cara merawat dan menampilkan tubuh sebagai bagian dari sosial. Tubuh manusia tumbuh di dalam budaya, agama, dan lingkungan tinggal sehingga proses disposisi dalam menampilkannya akan dipengaruhi oleh kecenderungan kecenderungan tersebut. Karakter karakter pada tubuh individu dapat berintegrasi secara lokal dan global.

Tubuh manusia yang berada di titik objektivitas, subjektivitas, maupun antara (grey area) menjadi pedoman bagaimana individu harus menempatkannya pada konteks yang sesuai, tradisi dan otoritas individu (Lury, 1998). Melalui posisi posisi tersebut, manusia mampu mengekspresikan tubuhnya sebagai bagian dari sosial dan menciptakan penilaian penilaian baru seperti cantik, indah, seksi, anggun, dan lain sebagainya. Selain tubuh dinilai secara fisik dan sosial, masyarakat juga menilai berdasarkan gender seseorang sehingga penilaian terhadap tubuh menjadi lebih kompleks dan matang. Tubuh sebagai kepemilikan individu harus mengalami disposisi pada cara penyampaian ekspresi melalui media - media yang tersedia. Gender menjadi standar penilaian baru dalam menyampaikan tubuh individu ke ruang publik.

Standar - standar yang diberlakukan oleh masyarakat untuk menilai tubuh juga tak luput dari proses transformasi atas pengaruh dari luar yaitu globalisasi. Standar baru yang dibawa oleh globalisasi pada tubuh seakan menambah referensi individu dalam mengekspresikan karakter tubuhnya. Hal ini secara tidak langsung melunturkan nilai - nilai lokal yang bersifat konservatif dan menciptakan inovasi inovasi yang dianggap sesuai dengan perkembangan masyarakat yang semakin dinamis. Melalui pakaian, tubuh manusia dan sosial kerap mengalami penilaian baru karena media tersebut mampu mengangkat 
Fitrayani Dian Rositadewi :

Kebaya: Belenggu Konservatif Perempuan Muslim

citra dan karakter tubuh seseorang. Pakaian sebagai bagian dari bentuk pencitraan tubuh manusia terhadap ruang sosial bersifat dinamis sesuai dengan perkembangan manusia itu sendiri. Keleluasaan tubuh mengakses ekspresi melalui pakaian menjelaskan bagaiamana manusia memiliki kemampuan untuk melakukan disposisi.

Kebaya merupakan jenis pakaian yang dipakai oleh kalangan wanita Jawa, khususnya di lingkungan budaya Yogyakarta dan Surakarta, Jawa Tengah. Baju kebaya dikenakan oleh kalangan wanita bangsawan maupun kalangan rakyat biasa baik sebagai pakaian seharihari maupun pakaian upacara. Kebaya merupakan pakaian tradisional yang umumnya telah dikenal di seluruh Indonesia, namun kebaya lebih identik dipakai oleh wanita - wanita Jawa. Model dan jenis kebaya pun berbeda di setiap daerah yang tersebar diseluruh wilayah Jawa. Mengenakan kebaya akan membuat wanita yang mengenakannya berubah menjadi seorang wanita yang anggun dan mempunyai kepribadian ${ }^{1}$. Tranformasi yang dilakukan oleh perempuan masa kini dilakukan agar sesuai dengan keadaan dari pemilik tubuh, seperti halnya perempuan muslim di Indonesia harus mengenakan kerudung atau jilbab sebagai penutup kepala sehingga mereka menyandingkan dua material yang memiliki makna berbeda antara kebaya dengan jilbab untuk memenuhi kebutuhan tersebut. Modifikasi itulah yang membawa kebaruan pada jenis kebaya.

\footnotetext{
${ }^{1}$ duniasosbud.blogspot.co.id
}

Pakaian sebagai salah satu media untuk mengekspresikan karakter dan citra tubuh seseorang memiliki pengaruh yang kuat terhadap penilaian - penilaian yang akan diberikan oleh masyarakat dan memunculkan stigma - stigma baru. Tanpa harus menyalahi standar yang ada, manusia mampu mengolah pakaian - pakaian tradisional untuk memiliki aksen modern dan indah sebagai bagian dari kreatifitas dan pemenuhan kebutuhan masyarakat yang dinamis. Keterbukaan tubuh sosial terhadap nilai - nilai baru yang dibawa oleh globalisasi berdampak pada cara penyampaiannya melalui pakaian. Modifikasi dilakukan agar semua kebutuhan manusia terhadap ekspresi tersampaikan, walaupun dalam konteks yang masih sama. Pakaian tradisional yang digagas sebagai warisan menjadi aset yang berharga bagi dunia mode untuk memunculkan karakter baru, serta menguatkan karakter lama dalam suatu pakaian. Mengapa perempuan muslim cenderung memodifikasi kebaya daripada merubah selera pada pakaian lain seperti gaun atau dress yang lebih tertutup?

Pakaian sebagai bagian dari ekspresi tubuh manusia bagi perempuan muslim telah diatur juga dalam Al Qur'an surat Al A'raf ayat 26 bahwa fungsi pakaian adalah penutup aurat dan perhiasan (Rubiyanti, 2004). Pakaian sebagai penutup aurat sudah jelas maksudnya untuk menutup bagian bagian tubuh perempuan muslim yang vital dan privat, sehingga orang lain bukan muhrim tidak mampu melihatnya. Pakaian sebagai perhiasan berfungsi untuk memperindah penampilan perempuan muslim di hadapan Allah dan sesama 
manusia. Menurut Koentjaraningrat (1990) pakaian bagi manusia merupakan wujud dari eksistensi individu yang berasal dari suatu kebudayaan tertentu yang menjadi tanda bagi individu tersebut, sehingga menjadi identitas bagi individu itu sendiri. Digunakan sebagai media untuk mengekspresikan tubuh seseorang pakaian akan diciptakan bersama aksen - aksen tertentu yang menjadi simbol sehingga pakaian merupakan salah satu bentuk kegiatan atau ungkapan simbolis yang sejajar dengan kegiatan simbolis lainnya (Sudiarja, 1983). Karena simbol adalah seluruh kegiatan mental manusia (Ernst Cassirer dalam Sudiarja, 1983 : 72). Maka pakaian mengandung simbol - simbol yang membangun identitas seseorang. Pakaian berperan besar dalam menentukan citra seseorang (Nordholt, 2005).

Secara fungsional, pakaian digunakan untuk melindungi tubuh individu dari berbagai bahaya yang mampu mengganggu kenyamanan maupun merusak bagian tubuh manusia. Namun seiring berjalannya waktu, pakaian perempuan khususnya mengalami banyak perubahan dari segi model, bahan, dan cara pemakaian. Hal tersebut terjadi karena perempuan mampu berkreasi dan memodifikasi pakaian sesuai dengan selera dan kebutuhannya. Dibandingkan dengan laki - laki, tubuh perempuan lebih mudah mengikuti hal hal baru sebagai bagian dari eksperimen ekspresi. Cara penyampaian ekspresi yang lebih bervariasi dan berwarna membuat pakaian perempuan dapat diolah menjadi berbagai macam mode atau style. Style atau gaya adalah replikasi dari pola, baik dalam perilaku manusia atau artefak yang dihasilkan oleh perilaku manusia, bahwa hasil dari serangkaian pilihan yang dibuat dalam beberapa hambatan (Meyer, 1987). Pakaian secara fungsional telah memberikan manfaat sebagai pelindung, lain halnya pakaian secara sosial. Pakaian merupakan ekspresi yang paling khas dalam bentuk material dari berbagai tingkat kehidupan sosial (Nurfiyanti, 2004). Orang bebas berkreasi dan memodifikasi bentuk atau mode pakaian agar terlihat lebih indah dan menarik. Dalam industri mode, pakaian wanita paling cepat berubah dan paling banyak variannya.

Kebudayaan bisa dijadikan sumber untuk menciptakan mode. Kebaya dan kain adalah salah satu jenis mode yang paling banyak mendapatkan pembaharuan dari perancang maupun konsumennya (Rubiyanti, 2004). Pakaian merupakan salah satu cara yang dipakai oleh seseorang untuk berinteraksi dengan orang lain. Pakaian selain sebagai barang yang harus dimiliki oleh setiap orang, ternyata pakaian juga mampu menunjukkan keberadaan status seseorang (Nurfiyanti, 2004). Pakaian adalah salah satu penanda yang paling jelas di antara penanda penampilan lainnya, sehingga mampu membedakan diri dari orang lain dan identifikasi oleh komunitas tertentu karena berpakaian akan menciptakan konsekuensi emosi atas apa yang dikenakan pada tubuh. Bagi perempuan muslim memadupadankan pakaian tradisional kebaya dengan jilbab merupakan salah satu inovasi yang sampai sekarang masih ditemukan.

Keberagaman gaya - gaya berpakaian kebaya oleh perempuan Indonesia termasuk perempuan muslim yang tinggal di Jawa. Kebaya sebagai salah satu nilai estetika perempuan Jawa sangat berperan 
Fitrayani Dian Rositadewi :

Kebaya: Belenggu Konservatif Perempuan Muslim

penting dalam pembentukan identitas feminin. Pakem - pakem yang ada dalam pakaian kebaya menonjolkan kesan tersebut ketika diaplikasi pada tubuh perempuan, dan hal tersebut oleh prempuan muslim Jawa ingin baurkan dalam aturan - aturan agama Islam. Pada pertemuan-pertemuan khusus diharuskan mengenakan kebaya untuk menunjukkan latar belakang budayanya namun juga tetap menutup aurat sebagai aturan agama (Van Dijk, 2005). Selanjutnya, modifikasi dunia fashion tak luput dari peran pasar sebagai penyedia kebutuhan akan ekspektasi - ekspektasi keindahan, kecantikan, dan keunikan. Kebaya sebagai bagian dari identitas nasional Indonesia walaupun banyak dipengaruhi oleh budaya Jawa. Pasar memproyeksikan keinginan perempuan muslim terhadap kebaya yang pantas untuk dikenakan saat acara formal dan hal tersebut dianggap sebagai kecenderungan untuk menghubungkan identitas, kultural, dan emansipasi (Van Dijk, 2005).

\section{Metode}

Penelitian ini merupakan bersandar pada studi literature dan teks media. Literatur telah menjadi dasar bagi pembahasan tentang bagaimana transformasi pakaian berlangsung dalam konteks yang luas. Pada saat yang sama berbagai bahan sekunder melalui media diakses untuk memperlihatkan selain pergeseran yang terjadi menguji bagaimana pandangan para pihak di dalam menempatkan kebaya sebagai pakaian dengan identitas budaya dan nasional. Sumber-sumber berita online telah digunakan untuk memperjelas objek studi yang dibicarakan. Berita online sebagai bahan yang diacu yang kemudian dianalis melalui kasus-kasus yang dapat diidentifikasi melalui sumber sekunder.

Dalam presentasi data digunakan metode pengutipan langsung untuk memperjelas data penelitian juga untuk membandingkan teks dengan konteks di mana fenomena kebaya ditemukan dalam masyaralat. Analisis teks digunakan dengan menemukan konsistensi dan koherensi untuk menjelaskan bagaimana teks dapat menggambarkan suatu peristiwa dan fenomena sosial. Pada saat yang sama, perbandingan teks dengan konteks memungkinkan diperoleh pengetahuan sejarah dan perkembangan dunia fashion sebagai bagian dari kekuatan konstruksi nilai. Pada saat yang sama, analisis sosiologis digunakan untuk melihat bagaimana pakaian dapat memberikan pengertian atas kehadiran seorang perempuan dalam suatu ruang sosial.

\section{Hasil Penelitian}

Kebaya sebagai pakaian tradisional dan adat Jawa telah dikenal luas oleh masyarakat Indonesia sejak era Ibu Kartini. Keberadaannya tak hilang begitu saja ditelan globalisasi dan kompleksitas masyarakat modern saat ini. Salah satu warisan budaya berupa pakaian memang bukan hanya kebaya saja. Namun, eksistensi dari kebayalah yang hingga sekarang masih diperhitungkan keberadaannya. Walaupun bukan menjadi jenis pakaian yang dapat digunakan setiap waktu, kebaya selalu menjadi pilihan perempuan Indonesia untuk berpenampilan anggun cantik, dan mempmesona. Hal 
tersebut karena aura dalam kebaya memancarakan sisi feminim dan berkelas, sehingga menjadi magnet setiap mata.

\section{Pembahasan}

Demi mempertahankan kebaya agar tetap berada dikelasnya, perempuan Indonesia berlomba - lomba untuk memadupadankannya dengan beberapa pakaian atau kain bahkan dari budaya suku bangsa lain di Indonesia. Upaya tersebut dilakukan karena masih banyak perempuan Indonesia yang gemar memakai pakaian tradisional kebaya dalam acara - acara formal. Nilainya yang tinggi di mata perempuan Indonesia secara umum, juga tak membatasi perempuan muslim khususnya di Jawa untuk menyandingkannya dengan jilbab maupun kerudung sebagai bagian dari kewajiban. Nyatanya, perpaduan tersebut menjadi salah satu temuan yang menciptakan mode kebaya di era modern.

Wikipedia Indonesia mendefinisikan kebaya adalah blus tradisional yang dikenakan oleh wanita Indonesia dan Malaysia yang terbuat dari bahan tipis yang dikenakan dengan sarung, batik, atau pakaian rajutan tradisional lainnya seperti songket dengan motif warna-warni. Menurut Denys Lombard dalam bukunya Nusa Jawa: Silang Budaya (1996) Kebaya berasal dari bahasa Arab 'Kaba' yang berarti 'pakaian' dan diperkenalkan lewat bahasa Portugis ketika mereka mendarat di Asia

Tenggara (nithadyatmikadewi.wordpress.com). Kata Kebaya diartikan sebagai jenis pakaian (atasan/blouse) pertama yang dipakai wanita Indonesia pada kurun waktu abad ke-15 atau ke-16 Masehi². Catatan mengenai nama kebaya ditemukan dalam catatan bangsa Portugis yang dulu pernah mendarat di Indonesia sekitar abad ke-16. Pada zaman dahulu, kebaya hanya dipakai di kalangan bangsawan di Pulau Jawa. Kebaya digunakan untuk acara-acara khusus, seperti acara perayaan keagamaan, dan lain-lain. Kemudian, kebaya menyebar ke Malaka, Bali, Sumatra, Borneo, Sulawesi, Sulu, dan Minadanao ${ }^{3}$.

Filosofi dari Kebaya, Bagi seorang wanita Jawa kebaya bukan hanya sebagai sebatas pakaian. Lebih dari itu kebaya juga menyimpan sebuah filosofi tersendiri. Sebuah filosofi yang mengandung nilainilai kehidupan. Keberadaan kebaya di Indonesia bukan hanya sebagai salah satu jenis pakaian. Bentuknya yang sederhana bisa dikatakan sebagai wujud kesederhaan dari masyarakat Indonesia. Nilai filosofi dari kebaya adalah kepatuhan, kehalusan, dan tindak tanduk wanita yang harus serba lembut. Karakter psikologis pakaian kebaya melambangkan keramahan, kelembutan, kesabaran, dan segala aura feminin merupakan manifestasi harkat dan prestise perempuan Indonesia. Kebaya selalu identik dipasangkan dengan jarik atau kain yang membebat tubuh.

Kain yang membebat tubuh tersebut secara langsung akan membuat siapapun perempuan yang mengenakannya kesulitan untuk bergerak dengan cepat. Itulah sebabnya mengapa perempuan Jawa selalu identik dengan pribadi yang lemah gemulai. Kain yang membebat tubuh juga akan membuat langkah kaki perempuan menjadi sedikit pendek. Mengenakan

\footnotetext{
${ }^{2}$ nithadyatmikadewi.wordpress.com

${ }^{3}$ Ibid.
} 
Fitrayani Dian Rositadewi :

Kebaya: Belenggu Konservatif Perempuan Muslim

kebaya akan pemakainya berubah menjadi lebih anggun dan mempunyai kepribadian. Potongan kebaya yang mengikuti bentuk tubuh akan membuat wanita tersebut menyesuaikan diri. Sesungguhnya filosofi dari penggunaan kain sebagai pelengkap kebaya nasional adalah, menunjukkan keanekaragaman budaya Negara Kesatuan Republik Indonesia (NKRI). Yang diperkaya oleh puluhan provinsi dan ratusan suku. Namun tetap menjunjung tatanan berbusanan yang seragam bagi perempuan, yakni kebaya nasional.

Indonesia memiliki banyak sekali warisan dalam hal kesenian dan kebudayaan. Salah satunya adalah kebaya. Kebaya yang berasal dan muncul dari kebudayaan Jawa telah bertransformasi dengan era globalisasi sehingga melahirkan berbagai macam jenis-jenis kebaya bergaya tradisonal maupun modern. Berikut ini adalah jenis -jenis kebaya yang ada di Indonesia4:

\section{Kebaya Kartini}

Model kebaya ini pada dulunya dipakai oleh perempuan nigrat saat era R.A Kartini. Jadi kebaya Jawa juga identik dengan sebutan kebaya Kartini. Potongan dari jenis kebaya ini mirip dengan kebaya Encim, yang membedakannya adalah lipatan pada bagian dada. Ciri lain dari kebaya Jawa adalah panjang kebaya yang menutup panggul, dan lipatan kerah dengan bentuk garis vertikal, yang membuat kesan pemakainya tinggi dan ramping. Dewasa ini Kebaya Kartini dibuat lebih sangat modern, mengikuti trend yang ada. Dan kadang-kadang dirancang dalam warna-

\footnotetext{
${ }^{4}$ nithadyatmikadewi.wordpress.com
}

warna meriah, tak hanya terpaku pada warna-warna kalem seperti putih, peach, khaki atau cream saja ${ }^{5}$.

Kebaya Jawa

Jenis kebaya ini memiliki bentuk yang simpel dengan potongan leher V. Motifnya biasa sehingga memberikan kesan sederhana. Biasanya kebaya Jawa terbuat dari kain transparan bermotif yang di padupadankan dengan pakaian dalam atas. Kebaya Jawa memiliki kekhasan berupa bahan nan menerawang, lembut dan melayang. Pilihan motifnya sungguh sangat banyak. Dari mulai kelopak-kelopak kembang besar, corak daun, brokat halus ataupun motif printing nan lebih kaya jenis dan pilihan. Panjangnya menutupi panggul. Kebaya Encim

Kebaya Encim merupakan perpaduan antara baju Shanghai khas China dan Kebaya khas Melayu. Kebaya Encim umumnya dibuat dengan bahan organdi atau katun. Yang membedakan kebaya ini dari jenis-jenis kebaya lainnya adalah, model kerah $\mathrm{V}$ dengan bordiran sepanjang kerah sampai bawah. Efek dari pemakaian kebaya encim ini adalah, pemakai nampak terlihat langsing, padat dan berjenjang. Kebaya encim mampu menutupi bentuk tubuh perempuan yang agak subur atau gemuk sehingga bisa menyembunyikan kekurangan bentuk tubuh.

Kebaya Bali

Kebaya Bali memiliki tambahan bentuk detail pada tambahan obi yang melilit pada bagian pinggang. Biasanya bahan dari kebaya Bali terbuat dari brokat dan kain katun. Tambahan obi yang ada bisa

\footnotetext{
${ }^{5}$ www.binasyifa.com
} 
langsung dipasangkan pada kebaya atau bisa ditambahkan kain yang terpisah dari kebaya.

Kebaya Kutubaru

Dasarnya bentuk kebaya Kutubaru sama dengan jenis-jenis kebaya lainnya. Yang membedakan adalah tambahan kain untuk menghubungkan sisi kiri dan kanan kebaya di bagian dada dan perut. Biasanya dalam pemakaian jenis kebaya ini ditambahkan stagen (kain yang dililitkan pada perut) atau korset supaya pemakaianya terlihat lebih langsing.

\section{Kebaya Modern atau Modifikasi}

Kebaya jenis ini biasanya sudah tak memegang pakem adat untuk menampilkan cirinya sehingga masuk ke dalam jenis lainnya. Kebaya modern atau modifikasi disesuaikan dengan tren pasar maupun kebutuhan si pemakai, para perancang pakaian di Indonesia gencar melakukan berbagai penemuan dalam mengkreasikan kebaya agar terlihat lebih berbeda dan memiliki nilai yang lebih. Pembentukan ide baru pada kebaya berusaha tak dilepaskan dari nilai budaya yang ingin disampaikan oleh perancang dan pemakaianya sehingga penting untuk mempertahankan detail pada bagian tertentu.

\section{Perkembangan Kebaya pada Perempuan Muslim}

Kebaya yang sekarang ini telah dianggap sebagai pakaian perempuan Indonesia secara nasional juga turut mengalami transformasi pada aplikasinya. Pada umumnya, kebaya digunakan dengan model ketat atau pres badan atau body fit sehingga lekuk tubuh seorang perempuan akan terlihat. Dahulu, perempuan
Indonesia dapat memakainya pada segala kesempatan namun setelah pakaian mengalami kemajuan dan memunculkan banyak model yang lebih praktis dan simpel, kebaya mulai ditinggalkan dan hanya digunakan pada saat tertentu saja seperti pernikahan, pertemuan formal, karnaval, dan acara adat. Kebaya yang kini berkembang di pasaran juga telah memiliki model yang berkembang, lebih banyak variasi pada bahan, warna, dan potongan, hal tersebut disebabkan nilai kebaya tak hanya untuk kalangan sosial tertentu saja, semua perempuan mampu menggunakannya. Kebaya juga diterapkan pada busana pengantin, khususnya pengantin Jawa. Untuk busana pengantin, kebaya mengalami modifikasi sehingga bisa juga digunakan para pengantin muslimah. Bahan yang digunakan juga bisa bermacammacam tergantung kebutuhan. Termasuk perempuan muslim yang masih mempertahankan warisan budaya materialnya, kebaya, jarik, dan selendang sebagai satu kesatuan outfit, namun perempuan muslim saat ini telah mengembangkan berbagai inovasi penggunaan kerudung, jilbab, atau hijab.

Perpaduan kebaya dengan tutup kepala muslim berupa jilbab atau hijab sudah banyak dikembangkan oleh perempuan muslim di Indonesia, guna memenuhi kewajiban mereka ketika bertandang ke suatu acara formal. Nilai kebaya yang sedang dipetahankan adalah nilai 'berkelas' dan anggun sehingga perempuan muslim juga dapat mengenakannya. Perpaduan kebaya dengan jilbab awalnya digunakan oleh para pengantin muslim yang tak ingin memperlihatkan auratnya di depan orang. Namun, mulai berkembang pada 
Fitrayani Dian Rositadewi :

Kebaya: Belenggu Konservatif Perempuan Muslim

perempuan lainnya yang melihat perpaduan tersebut tak menyalahi aturan. Berawal dari inovasi dari pemenuhan kebutuhan perempuan muslim akan kebaya yang menutup aurat, akhirnya keberkembangan tersebut disambut oleh pasar sebagai rumah para pembaharu dunia fashion. Pakaian kebaya warisan budaya Jawa yang telah menyatu dengan budaya lain di Indonesia, secara tidak langsung mendukung pembaharuan dalam style kebaya saat ini.

Kebutuhan atas kewajiban agama sebagai perempuan muslim dan keinginan untuk tampil anggun dengan balutan pakaian nasional menciptakan sensasi baru dalam mengenakan kebaya. Akhirnya, kebaya dapat dikenakan oleh perempuan muslim Indonesia dan memadukannya dengan kerudung yang sesuai warna agar terlihat berkolaborasi dan anggun. Tutup kepala berupa jilbab yang dikenakan juga tak hanya dibalut begitu saja, namun dimodifikasi agar sepadan dengan kebayanya. Ketelitian para stylist untuk menciptakan kesan glamor pada kebaya turut mendukung keberhasilan perpaduan antara dua material yang memiliki perbedaan nilai dan kesan. Kebaya sebagai bentuk konservatif terhadap budaya lokal dan kerudung atau jilbab sebagai material wajib untuk menutup aurat perempuan muslim. Walaupun kebaya diciptakan dengan mode body fit namun mampu disandingkan dengan kebutuhan perempuan muslim untuk menjaga auratnya dengan menambahkan sedikit aksen daleman atau manset untuk kamuflase.
Pengaruh budaya Islam juga tidak bisa dipungkiri karena istilah celana dan seluar, baju dan kebaya, etimologinya mengacu ke sebelah barat Samudra Hindia. Menurut kamus Hobson Jobson pada cetakan ulang, tahun 1969 berpendapat bahwa kata kebaya berasal dari bahasa Arab yaitu kaba yang berarti pakaian, namun diperkenalkan melalui bahasa Portugis. Islam yang tertutup dengan masalah seksual, dan menganjurkan untuk menutup aurat yaitu seluruh bagian tubuh merupakan dorongan di bidang usaha tekstil. Dari pakaian dapat mencerminkan perbedaan pangkat tetapi juga mode tertentu dan keanekaragaman daerah ${ }^{6}$.

\section{Hasil Penelitian \\ Modifikasi Kebaya Sebagai Konservasi Budaya}

Kebaya digagas sebagai pakaian khas Indonesia dan menjadi pakaian Nasional Indonesia berdasarkan perkembangannya, pakaian ini tidak lagi berfungsi sebagai pakaian daerah semata dan juga tidak hanya mewakili etnis tertentu saja, hingga saat ini kebaya telah dipakai dan dimiliki oleh masyarakat luas di Indonesia secara nasional sebagai pakaian resmi maupun sehari-hari. Di abad ke-19, pakaian jenis kebaya mulai familier dikenakan oleh masyarakat yang lebih umum, termasuk perempuan keturunan Belanda yang tinggal di Indonesia kala itu. Busana ini pun tak lagi didominasi oleh anggota kerajaan dan kaum priayi. Kemudian, di era 1940-an kebaya dipilih Presiden Soekarno sebagai kostum nasional yang menggambarkan identitas perempuan Indonesia.

\footnotetext{
${ }^{6}$ www.pesta-wedding.info
} 
Diangkatnya kebaya sebagai pakaian nasional bangsa oleh presiden saat itu mengakibatkan keberagaman pilihan perempuan Indonesia untuk mengenakannya di berbagai acara formal yang melibatkan proses kontentasi nasionalisme.

Indonesia adalah negara kepulauan yang terdiri atas berbagai suku bangsa sehingga memiliki banyak ragam budaya dan tradisi. Ragam budaya tersebut tampak dari bahasa, adat istiadat, kesenian tradisional, dan sebagainya. Keanekaragaman budaya merupakan warisan bersama yang dimiliki bangsa Indonesia, serta harus dilestarikan oleh kita sebagai penerus bangsa. Salah satu warisan kebudayaan Indonesia adalah pakaian tradisional. Dari berbagai pakaian tradisional yang ada di Indonesia, kebaya ditetapkan sebagai kostum nasional. Kebaya dianggap paling ideal untuk mencerminkan keanggunan sosok wanita Indonesia. Hal tersebut bercermin dari filosofi dan nilai - nilai yang ada pada kebaya sehingga diharapkan mampu dipancarkan melalui tubuh perempuan. Kebaya sebagai bentuk legitimasi perempuan atas keanggunan dan kepribadiannya sehingga acara - acara formal digunakan sebagai media kontestasi.

"Fashion is a significant expression of cultural identity. Identity, then, like language, was not just a description of cultural belonging; it was a sort of collective treasure of local communities" (John Tomlinson, 2003) ${ }^{7}$.

${ }^{7}$ www.dewimagazine.com
Dalam hal ini, kebaya diangkat sebagai model untuk menunjukkan satu identitas yang kuat antar rakyat Indonesia khususnya perempuan. Warisan budaya ini mengandung nilai - nilai luhur bagaimana manusia atau rakyat Indonesia mengenal peradaban untuk menutup tubuhnya sebagai lokasi yang pribadi sehingga terbentuk moral bangsa. Selain identias, kebaya digunakan untuk mendekatkan pribadi manusia dengan latar belakang kebudayaannya, senses of belonging, ketika merasa jauh dan rindu terhadap tanah air. Ekspresi - ekspresi yang dingin disampaikan kepada orang lain atas pribadi diri dapat tersalurkan melalui kebaya yang dikenakan karena pakaian adalah instrumen paling luar yang mudah dikenal sehingga tanpa mengutarakannya secara langsung.

Kebaya juga digunakan untuk memperjelas hierarki sosial perempuan Indonesia di mata masyarakat umum sebagai artikulasi dari batas - batas tubuh individu dan pribadi dari aspek yang berbeda dari proses yang sama (Falk, 1994). Selain berfungsi untuk menonjolkan identitas dan nilai sosial, kebaya juga digunakan sebagai wadah untuk mengikat perempuan Indonesia memperjuangkan hak-hak kesetaraan terhadap laki - laki seperti isu - isu yang tersebar di media masa. Kebaya menjadi salah satu contoh bentuk pembuktian bahwa perempuan juga memiliki nilai yang berharga di mata bangsa Indonesia. Pakaian adalah kulit sosial dan kebudayaan sehingga berperan besar dalam menentukan citra seseorang dan dapat dilihat sebagai perpanjangan tubuh, namun sebenarnya bukan bagian dari tubuh (Nordholt, 2005). 
Fitrayani Dian Rositadewi :

Kebaya: Belenggu Konservatif Perempuan Muslim

Indonesia adalah salah satu negara yang memiliki masyarakat mayoritas beragama Islam sehingga banyak dari kebutuhan umum harus dilandasi oleh peraturan agama. Islam sebagai agama yang telah lama masuk dan hidup di Indonesia melalui perdagangan - perdagangan kuno masa kerajaan, menyebar dan menetap bahkan mempengaruhi cara hidup masyarakat. Dalam Al Qur'an sudah dijelaskan bahwa perempuan muslim harus mengenakan penutup kepala berupa kerudung, jilbab maupun hijab ketika keluar rumah dan bertemu dengan non-muhrim. Kemunculan kerudung dalam kehidupan orang Indonesia memang bukan hal baru, pada tahun 2000-an, masyarakat telah mengenal jilbab sebagai bagian dari identitas agama namun masih sedikit yang menggunakannya dan model yang digunakan pun sangat sederhana. Kerudung atau jilbab sebagai identitas agama selama periode tersebut juga masih menimbulkan stigma, di mana para penggunanya dianggap anggota dari komunitas penganut Islam ekstrim dan sebagainya. Seiring berjalanannya waktu, pada tahun 2010-an, kerudung atau jilbab sudah tak lagi dieksklusifkan pada golongan perempuan tertentu melainkan sudah menjamah berbagai kalangan seperti ibu rumah tangga, penjual, dan wanita karir. Saat ini, kerudung atau jilbab yang dikenakan oleh perempuan muslim telah bertransformasi menjadi bagian dari pakaian yang mencerminkan ekspresi cara hidup Islam dan hubungan religius (Nordholt, 2005).

"Dan katakanlah kepada perempuanperempuan yang beriman supaya menyekat pandangan mereka (daripada memandang yang haram) dan memelihara kehormatan mereka dan janganlah mereka memperlihatkan perhiasan tubuh mereka kecuali yang zahir daripadanya, dan hendaklah mereka menutup belahan leher bajunya dengan tudung kepala mereka, dan janganlah mereka memperlihatkan perhiasan tubuh mereka melainkan kepada suami mereka atau bapak mereka atau bapak mertua mereka atau anak-anak mereka, atau anak-anak tiri mereka atau saudara-saudara mereka atau anak bagi saudara-saudara mereka yang lelaki atau anak bagi saudara-saudara mereka yang perempuan, atau perempuan-perempuan Islam atau hamba-hamba mereka atau orang gaji dari orang-orang lelaki yang telah tua dan tidak berkeinginan kepada perempuan atau kanakkanak yang belum mengerti lagi tentang aurat perempuan dan janganlah mereka menghentakkan kaki untuk diketahui orang akan apa yang tersembunyi dari perhiasan mereka dan bertaubatlah kamu sekalian kepada Allah, wahai orang-orang yang beriman, supaya kamu berjaya" (QS: An-Nur, 31).

Kemajuan kerudung atau jilbab dalam ruang publik juga banyak mengalami hambatan berupa larangan untuk menggunakannya di sekolah dan kantor dengan alasan yang dianggap tidak jelas dan terlalu menyudutkan masyarakat, khususnya perempuan muslim. Perdebatan mengenai kerudung atau jilbab sebagai pakaian perempuan muslim juga menyediakan bahan debat di kancah budaya karena adanya pertemuan ideology-ideologi karena pakaian tak hanya dimaknai sekedar menandai perbedaan dan persamaan dalam masyarakat melainkan sebagai cara hidup (Nordolt, 2005). Lambat laun, keberadaan kerudung atau jilbab sudah dapat diterima masyarakat luas 
sebagai bagian dari mode pendukung pakaian. Selain itu, pengaruh Islam di Indonesia khususnya Jawa sangat menonjol dan mempengaruhi ekspresi - ekspresi tentang restorasi nilai - nilai Jawa dalam latar Islam. Walaupun aturan agama untuk menutup aurat perempuan sangat ketat, namun para perancang maupun innovator kebaya tak ingin membuat kaum perempuan muslim menjadi terdiskriminasi karena tidak mampu menggunakan pakaian adat tradisonal Jawa kebaya untuk menghadiri acara - acara formal.

"The presentation of emotions must be managed and altered in light of stereotypes and widely held assumptions about identity" (Otis, 2012).

Kerudung atau jilbab telah mengalami banyak tantangan untuk dapat diterima oleh masyarakat luas bahkan pembuat kebijakan agar diakui sebagai bagian dari atribut pakaian perempuan muslim di Indonesia dan tuntutannya terhadap agama. Permasalahan agama beserta atributnya memang dekat dengan kehidupan bangsa Indonesia yang bersifat majemuk namun tetap menjunjung tinggi rasa toleransi antar sesama. Menurut Hassan (1985) dalam Nordholt, para pemimpin keagamaan yang tidak terlalu radikal memaafkan pakaian - pakaian baru meski tetap menekankan agar masyarakat tidak perlu malu untuk memperlihatkan bahwa mereka adalah orang muslim melalui cara berpakaian. Kerudung atau jilbab dalam hal ini dianggap sebagai simbol presentasional yang mampu menyampaikan makna dan pemahamannya tidak bergantung pada hukum yang mengatur unsur - unsurnya (pakem kebaya), melainkan intuisi langsung dan sebagai kesatuan yang utuh sehingga ekspresi yang ditonjolkan dalam estetika pakaian dapat berinteraksi dengan pihak lain (Sudiarja, 1983). Maka, perpaduan antara kebaya modifikasi dengan kerudung atau jilbab diharapkan mampu memenuhi kebutuhan perempuan muslim untuk tampil anggun dalam balutan pakaian tradisional dan nasional Indonesia.

"It is particularly characteristic of fashion -because, by its very essence, it can be a norm which is never satisfied by everyonethat it renders possible a social obedience that is at the same time a form of individual differentiation" (Frisby \& Featherstone, 2000).

\section{Faktor Pembentukan Mode pada Kebaya Tradisional}

Dalam dunia perkembangan mode, pakaian tradisional warisan budaya menjadi aset yang berharga. Walaupun bukan menjadi hal yang baru, kebaya selalu dihadirkan dengan kemasan yang baru setiap pergantian mode di Indonesia. Perempuan menjadi objek dari perkembangan yang terjadi di pasaran karena inovasi - inovasi terus diharapkan untuk mendukung penampilan terluar agar tetap menarik dan anggun. Kebaya zaman dulu memang terkesan jadul jika dibandingkan dengan zaman sekarang. Maka dari itu para perancang busana selalu berkreasi dengan kebaya agar tidak dipandang sebelah mata. Saat ini, banyak variasi kebaya karena oleh wanita dari berbagai pelosok di Indonesia. Para perancang busana pun seringkali 
Fitrayani Dian Rositadewi :

Kebaya: Belenggu Konservatif Perempuan Muslim

menelurkan ide-ide mereka dalam beragam kebaya modern agar kebaya dapat diterima oleh masyarakat. Beragam inovasi dilakukan agar kebaya dapat terus dilestarikan di Indonesia. Modifikasi kebaya dilakukan oleh desainer-desainer, untuk memenuhi kebutuhan beberapa perempuan Indonesia yang menginginkan adanya perpaduan nilai - nilai budaya dengan agama sebagai identitas.

"Selain memiliki fungsi estetis,
kebaya juga memiliki fungsi
sosial sebagai pembelajaran
untuk wanita agar berpakaian
rapi, pantas dan senantiasa
menjaga kehormatannya
(Setiawan, 2009: 6-7). Seperti
yang dikatakan oleh seorang
perancang kebaya bahwa kebaya
adalah sebuah busana yang
memiliki ruh. Ketika seorang
perempuan, siapa pun dia,
mengenakan kebaya, akan ada
sesuatu yang berbeda dari
penampilannya. Itulah keunikan
kebaya. (Ivan belva, 2013).
Selain itu, kebaya sebagai
busana tradisional mampu
mencitrakan kepribumian (Ria
Pentasari,
(www.dewimagazine.com).

Pembentukan mode baru pada kebaya yang dikenakan oleh perempuan Indonesia disesuaikan dengan kebutuhan perempuan itu sendiri. Transformasi pada beberapa bagian dari kebaya dimaknai sebagai bentuk komunikasi antar pemakai maupun ke orang lain secara simbolik sehingga perubahan selalu membawa alasan tersendiri dalam kehadirannya dan menciptakan definisi terhadap si pemakai
(Barthes, 1983). Termasuk perpaduan kebaya dengan jilbab pada perempuan muslim, transformasi tersebut telah dimaknai sebagai inovasi yang wajar melihat banyaknya perempuan Indonesia yang beragama Islam dan berupaya untuk menjaga auratnya. Kegiatan pemenuhan kebutuhan akan kebaya muslim menurut Lury (1998) disebut budaya konsumen sebagai proses sukarela, pengarahan diri, dan kreatif yang mengikutsertakan nilai nilai dan ideal - ideal budaya karena masyarakat mempunyai hasrat independen untuk mengejar kesenangan. Kebaya modifikasi atau kebaya modern lebih sering muncul dalam acara - acara tertentu saja seperti pernikahan, wisuda, formal, bahkan kenegaraan. Aura keanggunan yang dipancarkan oleh kebaya melalui tubuh perempuan juga tak luntur jika dikenakan oleh perempuan muslim yang menggunakan jilbab sebagai penutup kepala karena mampu menampilkan aksen glamor pada kebaya. Perkembangan atau manipulasi yang terjadi pada pakaian kebaya juga dianggap sebagai jalan keluar bagi orang - orang yang ingin terbebas dari aturan-aturan yang mengikat sehingga mode adalah tindakan kecenderungan menuju pemerataan sosial dengan keinginan untuk diferensiasi individu dan variasi (Frisby and Featherstone, 1997). Transformasi pada mode pakaian kebaya tak luput dari peran negara, budaya, dan lembaga agama yang tidak secara langsung terlibat dalam proses produksi dan reproduksi simbol dan gambaran mental (Abdullah, 1995). Isu globalisasi pun turut andil dalam berbagai kemunculan mode pada pakaian kebaya di Indonesia selain 
untuk memenuhi kebutuhan perempuan Indonesia juga diperkenalkan kepada dunia bahwa kebaya adalah warisan budaya leluhur yang mampu bertahan dalam era era modern tanpa harus menghilangkan nilai kepantasannya sebagai pakaian nasional bangsa Indonesia. Kebaya saat ini juga telah mengilhami banyak ekspektasi sehingga kehadirannya bersifat luwes dan lentur terhadap perubahan dan kemajuan zaman.

\section{Kesimpulan}

Kini, kebaya dianggap pula sebagai simbolisasi emansipasi perempuan, melekat dan sering dikonotasikan dengan tokoh kebangkitan perempuan. Busana nasional perempuan Indonesia adalah kebaya yang sekarang ini telah dipengaruhi oleh budaya global, sehingga dalam berkebaya terlihat lebih santai dan lebih mudah disesuaikan dalam kondisi apapun. Nilai yang melekat pada pakaian kebaya menciptakan identitas seseorang yang mengenakannya sehingga dalam kreativitas dan beragam inovasi untuk melakukan transformasi pada mode kebaya pada era globalisasi saat ini kerap bersifat bebas dan praktis. Transformasi yang dilakukan oleh perempuan muslim oleh masyarakat umum telah mengalami penerimaan dan dianggap wajar karena kebutuhan yang wajib. Jilbab dan kebaya sering dipertemukan dalam acara - acara tertentu yang bersifat formal sehingga kesan anggun, indah, menarik, dan glamor masih tetap terjaga. Setelah digagas sebagai pakaian nasional bangsa Indonesia, kebaya mulai diminati oleh seluruh kalangan sosial. Tak ayal, modifikasi - modifikasi yang dilakukan pun diperlukan untuk memenuhi ekspetasi masyarakat akan keanggunan perempuan dalam kebaya. Kebaya modifikasi yang dikenakan oleh perempuan muslim Indonesia masuk sebagai gaya hidup merupakan wahana ekspresi di masyarakat yang mencampurkan nilai - nilai tertentu dari agama, sosial, dan kehidupan moral melaui bentuk - bentuk yang mencerminkan perasaan (Adlin, 2006).

Saat ini, kebaya yang lebih banyak dikenal adalah kebaya modifikasi. Bila dilihat dari fungsi pemakaian dan nilai value di masyarakat, kebaya pada setiap zaman terus mengalami pergeseran. Berawal dari hanya bisa dipakai oleh para bangsawan, sampai digunakan untuk busana sehari-hari oleh rakyat biasa dan sekarang ada kecenderungan para pemuda menggunakan kebaya hanya khusus dipakai pada acara - acara tertentu saja, tidak sebagai pakaian sehari-hari. Oleh karena kebaya adalah bagian dari budaya asli yang tak bisa dipisahkan dari Indonesia, sudah sepatutnyalah kita sebagai bagian dari bangsa Indonesia turut andil dalam usaha melestarikan kebaya mengingat sejarahnya yang panjang dan kekhasannya yang tak tergantikan. Romantisme budaya yang tercermin dalam kebaya selalu direproduksi dari masa ke masa agar kenangan masa lalu akan keanggunan perempuan Jawa yang dewasa ini telah disimbolkan untuk perempuan Indonesia secara menyeluruh termasuk perempuan muslim. Walaupun sudah tak ketat dalam mengikuti pakem yang ada, kebaya modifikasi tetap memancarkan aura keserhanaan dan keanggunan perempuan dalam berbagai situasi. Perpaduannya dengan berbagai kain dan penutup kepala seperti jilbab atau kerudung tak 
Fitrayani Dian Rositadewi : Kebaya: Belenggu Konservatif Perempuan Muslim

mengurangi keindahan kebaya yang dikenakan. Sifat konservatif yang ada pada kebaya membuatnya terlihat cocok dikenakan pada acara - acara formal dan aura feminine juga akan mempengaruhi perilaku dan sikap perempuan saat mengenakannya. Perubahan budaya dan zaman menuntut penyikapan dari agama, namun dapat menimbulkan gerakan resistensi terhadap gaya hidup sehingga romantisme memang diperlukan sebagai gambaran untuk membangun idelisasi kekinian agama (Adlin, 2006).

\section{Daftar Pustaka}

Abdullah, Irwan. 1995. The Students of Yogyakarta : Market, Consumption and Lifestyle Management. Yogyakarta : Gadjah Mada University.

Adlin, Alfathri. 2006. Resistensi Gaya Hidup : Teori dan Realitas. Yogyakarta : Jalasutra.

Barthes, Roland. 1983. The Fashion System. New York : Hill \& Wang

Falk, Pasi. 1994. The Consuming Body. London : Sage.

Featherstone, Mike and David Frisby. 2000. Simmel on Culture. London : Sage.

Haviland, William A. 1995. Antropologi Edisi Keempat. Jakarta : Penerbit Erlangga.
Koentjaraningrat. 1985. Beberapa Pokok Antropologi Sosial. Jakarta : Dian Rakyat.

1990. Sejarah Teori Antropologi 2. Jakarta : UI - Press.

Kebudayaan di Indonesia. Jakarta : Djambatan.

Lang, Barel. 1987. The Concept of Style. New York : Cornell University.

Lury, Celia. 1998. Budaya Konsumen. Jakarta : Yayasan Obor Indonesia.

Nordholt, Henk Schulte. 2005. Outward Appearances. Yogyakarta : LKiS.

Nurfiyanti, Veri Dian. 2004. Fenomena Jilbab Gaul di Kalangan Mahasiswa UII : Identitas Muslimah dan Gaya Hidup Modis di Yogyakarta. Yogyakarta.

Otis, Eileen. 2012. Market and Bodies. California : Stanford University Press.

Rubiyanti, Eka. 2004. Tampil Modis dengan Berjilbab : Sebuah Trend Mode Masa Kini di Yogyakarta. Yogyakarta.

Sastrapratedja, M. 1983. Manusia Multi Dimensional. Jakarta : PT Gramedia. 